$\xi=-1$ 圆

\title{
Influence of Board Reformation on the Stock Returns: an Event Study
}

\author{
Bindya Kohli ${ }^{1 *}$, Deepa Pillai $^{2}$ \\ ${ }^{1}$ Symbiosis School of Banking and Finance, Pune-India \\ ${ }^{2}$ Symbiosis School of Banking and Finance, Pune- India \\ *Corresponding author E-mail: bindyakohli@ssbf.edu.in
}

\begin{abstract}
Investor sentiments pertaining to stocks are propelled by the contentions of financial sector reforms, fiscal policy and management change. Any uncertainty has a significant impact on the stock prices and returns accruing to the company. The paper examines the effect of change in management on the stock returns of a corporate entity. Organizational performance is dependent on the realization of the numerous roles the board of directors are entrusted with. Any change in the composition of the board through the resignation, retirement or ouster can thus have a significant impact on the stock prices and returns accruing to the company. It is anticipated that voluntary resignations, age related turnovers have small or negative impact on the stock price reactions. The paper investigates the impact of the ouster of the Chairman of the Tata group on the volatility of the daily prices and returns of four companies under the Tata umbrella. Event study methodology has been adopted following the market model of return generating process. Investors react to the market information thereby affecting the security prices positively or negatively during the event window. The findings disclose market sentiments are affected on the occurrence of the event though the acceptance of the event may be unforeseen.
\end{abstract}

Keywords: Abnormal returns; Board composition; Daily average returns; Event study; Governance; Stock returns

\section{Introduction}

Literature evidences that stock prices are predictable however they may exhibit reversal on weekly on annual basis. Research indicates that stock prices drift after important corporate events which are also driven by the overreaction of investors to these set of events. Investors have a tendency to react to unobserved or unanticipated stimuli. Event study methodology is apparently applied to examine earnings drift due to corporate action. Board of director's form a crucial governance mechanism as they are increasingly being held responsible for the organizational performance. Strategic decisions are based on direct control and supervision thus the business environment affects the performance of the board. Testing the importance of managers on firms' outcomes is challenging as it is difficult to find factual direct board effects. The objective of the paper is to investigate the effect of significant managerial event on the pre and post stock returns. Malmendier and Tate (2005) study illustrates that measures of board members behavioral traits and other personal characteristics affect firm investment decisions in the long run. Literature enumerates conflicting results between the change in management and the stock returns, however Warner et. al. (1988) study shows an association between the frequency of management turnover and the stock performance. Studies interrogate whether there exists a foreseeable difference in the stock price post the news broadcasts. Literature evidences that forced turnover can be facilitated by the industrial houses however dearth of literature exist for listed entities.

The research investigates the impact of a leadership change on the firm's stock prices by using a sample firm of representative companies from different sectors under the Tata Group of companies
(Tata Consultancy Services Ltd. Tata Steel Ltd. , Tata Motors Ltd. And Tata Power Ltd.). The real effect was measured in terms of stock returns of the representative companies with the Nifty 50 benchmark index. The paper studies the daily returns of security of the selected firms based on the daily abnormal returns to derive the expected price of the individual stocks.

\subsection{Company Background - the TATA Group}

Tata Group, is one of the largest and oldest business groups in India can be traced from Jamsetji Nuwan Tata's vision, commitment, passion and fortitude. Tata being a business group has diversified which is evident from Jamsetji Tata's dream for India. He envisaged three projects- an Iron and steel plant, hydroelectric project and a Science University which commenced between from 1908 to 1911 (Harris, 1958; Lala, 2004; Saklatavala and Khosla, 1970; Sivakumar, 2007, Kakani and Tejas Joshi, 2006). Tata's philosophy and ethical business practices were abided by each company working independently.

In 1981, Ratan Tata was nominated as the Chairman of Tata Sons and subsequently was made the Chairman of Tata Industries Ltd where he played a significant role in transforming Tata Industries Ltd. from a small company into a strategy think tank. In the year 1991 when Mr. Ratan Tata took charge as, he battled with the then power centres for around 4 years to get his team in place and for decades under his leadership Tata Group enchased on many business possibilities that they have entered and as well as exited. Tata group focuses on leadership and talent management their belief that company's success is dependent on right talent pool and skills across all domains with importance being given to diversity.

Several management structure transitions took place over the decades one such event occurred on $24^{\text {th }}$ October, 2016 as Cyrus Mis- 
try was discharged from chairmanship of the India's largest conglomerate Tata Group and was replaced by his predecessor Ratan Tata for the interim period. It was an experiment in succession that did not work for Tata Leadership and was one of the unexpected twist in the history of corporate India. The unexpected situation led to a war of words between Cyrus Mistry and Tata Sons. It was observed that during Cyrus Mistry's reign the total market value of all listed companies of Tata Group had almost doubled. However during Ratan Tata's chairmanship, the growth was 57 times more. With approximately 4.1 million shareholders the Tata Group is the country's most valuable group.

\subsection{Motivation of the Study}

Tata Companies on Nifty 50 index constitutes the sample which is consciously considered as a family run business it transformed and diversified its business into multiple corporate entities. TATA Group of Companies is a renowned name in the corporate sector and has taken a lead role in enhancing the brand appeal of Indian Industrial Sector. Belief is a decisive element of market sentiments thus Tata group exemplifies trust and has been India's most diversified business conglomerate with multiple companies spread across nations. Tata's has diversity across sectors ranging from manufacturing to services and beyond whilst benchmarking itself with the highest ethical standards which has been a persuasive parameter for applying event study. Tata companies listed on the stock exchanges are considered to be the bellwether stocks which have a significant weightage in the indices. The decision to remove Cyrus Mistry as the Chairman of the Tata group was a critical decision to which the markets may have overreacted or underreacted which the paper aims to study. The present study aims to analyze the impact of the decision on the performance of 4 companies in which Cyrus Mistry was the Chairman.

The study attempts to address the questions: is there some unusual behavior between the rates of return to the stock holders surrounding the management change and secondly if management change is associated with unusual behavior of security returns and to what extend it can be accounted for by the relationships between the variables.

\section{Literature Review}

Koch and Fenili (2013) opine that event studies aim at investigating the impact of unexpected scenarios and new information on share returns. These studies examine the impact of events on company valuations through a proxy in the form of stock prices. Event studies are applicable both at the micro level: firm specific and at the macro level: economy specific. Unexpected events may have an impact on the profitability of the firm or affect the riskiness, resulting a change in the stock prices. Event studies offer insights into issues of bad news affecting bank's stock returns, Schweitzer (1989). Event studies utilize the firm's actual stock price return after a specific event or announcement and compares it with a share price return that would have accrued assuming the event never took place. The difference between the two is an "abnormal return". Event studies are conducted across domains of finance, economics and marketing. Previous studies indicate impact on share returns post announcements such as corporate earnings, dividend declaration, stock splits, product recall, executive compensation policy and mergers and acquisitions. Bowman (1983), Armitage (1995), MacKinlay (1997), McWilliams and Siegel (1997), Binder (1998), and Johnston (2007) have catalogued many of these studies and also have evaluated some of the theoretical and empirical underpinnings of these studies.

Chance and Ferris (1987) investigated how the stock returns of various airlines were affected due to 46 airplane crashes, the impact was tested for both the airlines whose plane had crashed as well as other airlines in the industry. They found that the carriers involved in an airplane crash witnessed an average loss of 1.2 percent of their market cap one trading day following the crash.
Carvalho et al. (2011) analyzed the impact of an incorrect news about a prospective bankruptcy declaration by United Airlines in 2008. United's share price tanked by 76 percent after the false announcement and continued to fall more than 11 percent even after the public were made aware of the erroneous piece of information. In another study Swary (1986) investigated the market's reaction in 1984 to the bad-news that Continental Illinois National Bank was in financial distress. This event study, conducted on a consortium of large banks, found significant negative abnormal returns (approximately 3 percentage points) following the news of Continental's distress.

Worrell et al. (1986) studied the impact of a sudden death of a company's CEO (including CEOs-only and CEOs Chairmen) and found that the event adversely affected firm's value. Similarly, Johnson et al. (1985) conducted an event study of unexpected deaths of 47 CEOs, Chairmen and Presidents (founding executives) and found that the deaths led to positive abnormal returns of the respective companies. Contrary to this, Koch et al. (2011) investigated the impact of a fake news related to Steve Jobs. They found that the internet news relating to Steve Jobs suffering a heart attack did not have a considerable impact on Apple's share price. They did, however, find that by the end of the event period, the actual price was higher than the counterfactual price. In another set of studies focusing on mergers and acquisitions, Jack Trifts and Kevin Scanlon (1987) investigated analyzed the effect of interstate bank mergers on banks' stock returns and found that the target banks experienced significant positive abnormal gains. Similarly, Michael Jensen and Jensen et al. (1983) event analysis reveals that the shareholders of targeted firms gain significant, positive abnormal returns of almost 30 percentage points. In the case of unsuccessful merger shareholders of targeted firms gained some positive returns when the merger was initially announced, but lost these gains when it became certain that the merger would not go through.

The first event study by Furtado and Rozeff (1987) analyzed the impact of forced managerial turnover in the US on the respective share prices and found that though the change in the stock price was positive it was statistically insignificant. Researchers have also analyzed the impact of CEO turnovers. The analysis suggest that any type of change in the top management or Board makes the stock prices volatile Furtado and Karan (1990) elucidated 10 studies that analyzed and evaluated the impact of CEO changes on stock returns. They witnessed abnormal returns to be around 25 to 50 basis points for all types of senior leadership changes. Berkovitch and Israel (1996) as well as Grinstein (2000) suggested that stocks witnessed higher variations post managerial change. On comparing forced and voluntary turnovers, it was observed that forced turnover led to a higher volatility in the prices than voluntary turnovers. This is in consonance with the view that forced departures entails a higher likelihood of significant strategic overhauling accompanied by uncertainty about the future direction of the company, Rosenberg et al (2003). In contrast, Dewatripont and Tirole (1994) suggest that turnovers lead to a drop in the volatility.

\section{Methodology}

\subsection{Identification of the Event}

The authors have used event study methodology for estimating the impact of the ouster of the Chairman of the Tata Group on the daily returns of 4 companies under the group. However for measurement perspective we have narrowed down the date of event as date of announcement and event window as the post announcement period in order to capture the stock market reactions. After examining the Tata Group of companies, top four companies were selected based on the market capitalization and listing on Nifty 50 . 
The companies included Tata Motors, Tata Consultancy Services, Tata Steel and Tata Power. Bondt and Thaler (1985) study suggest that there always precedes a possibility that investors may overreact to an unexpected and untoward news events pertaining firm specific or industry specific which has been identified in the extant literature. Chan (2003) study indicates increase in trading volumes as an effect of investor's reactions due to news shocks. Prior work validates that news that are extremely relevant and original tempts a greater impact on stock prices. There has been noticeable number of news items that have occurred from $1^{\text {st }}$ September to $21^{\text {st }}$ October, 2016.

\subsubsection{Postulates}

The paper postulates that any change in the management structure may have a positive or negative impact on the performance of the firm affecting the shareholders' wealth maximization proposition. The paper antedates to test the efficient market theory which propounds that impact of an event will be immediately discounted and depicted in stock prices. Thus the stock returns accruing over the event period are a good indicator of the market reactions to a particular event. A priori it is unclear whether death of chairman or change in the management control results into negative, positive abnormal returns discussed by Haynes and Schaefer (1999) in their study further it states that incremental value of cash flows a firm will realize from the employment of new key personnel. The paper first discuss the statistical properties of both the benchmark returns (Nifty 50 returns) and the daily excess returns. It is presumed that the daily stock returns and abnormal returns may exhibit abnormality which are not observed with monthly data.

\subsubsection{Daily Stock Returns (Dars)}

The data on stock's closing prices and the NIFTY were obtained from Capitaline Database.

An event study considers a stocks actual return after a particular event and compares it to a counterfactual return that would have accrued had the event not taken place. The difference between the actual and assumed return is the abnormal return or loss.

The returns of specific stock were first measured by the first logarithmic difference of respective indices, the return for daily stock price index was calculated as:

$\mathrm{R}_{\mathrm{t}}=\log \mathrm{r}_{\mathrm{e}}-\log \left(\mathrm{r}_{\mathrm{e}}-1\right)$

$R_{t}$ and $r_{e}$ are the closing prices of the representative stocks and return on the $T_{\text {th }}$ day.

If the number of trading days post event taken are more than one Daily Abnormal Returns (DARs) for each of the days are computed, followed by the Cumulative Abnormal Returns (CARs) which are the accumulation of DARs of the days post the event. This post event time period is generally of a short span as it should be free of any contamination by other events or factors. The researchers have taken the post event window from $24^{\text {th }}$ October, 2016 to $7^{\text {th }}$ November to avoid the impact of demonetization that was announced on $8^{\text {th }}$ November, 2016.

An estimation period prior to the event is also taken for both the scrips selected and the market as a whole to understand if the markets were stable or were experiencing any volatility.

The returns on the securities were calculated by using the formula $\ln \left(S t / S_{t-1}\right)$. Similar methodology was used to estimate the returns on the NIFTY 50 for both the estimation and event period. Using the regression equation

$R_{t}=\alpha+\beta R_{m t}+\varepsilon_{t}$

for estimation period, the values of $\alpha$ and $\beta$ were calculated. These were then used to calculate the DARs in the event period by using the formula: $D A R g=R_{g}-\left(\alpha+\beta R_{m g}\right)$

Where, $\alpha$ and $\beta$ are the coefficients obtained from the regression equation, $g$ is the particular day of the event. In the paper, $g$ varies from 1 to 10 days (from $24^{\text {th }}$ October, 2016 to $7^{\text {th }}$ November, 2016). Finally the Cumulative Abnormal Gains were calculated for all 4 companies for the 10 days.

This was followed by comparing the actual prices of the stocks during the event period with the prices that would have existed had the event not taken place. The predicted prices were calculated by dividing the actual closing prices of the stocks on a particular event day by the antilog of the abnormal returns on that day. The sampling frame is depicted below:

Sample units- Tata Motors, Tata Consultancy Services, Tata Steel and Tata Power. The Benchmark Index was Nifty 50. Estimation period- $1^{\text {st }}$ September 2016 to $21^{\text {st }}$ October 2016.

Event date- $24^{\text {th }}$ October, 2016; Event period-24 ${ }^{\text {th }}$ October 2016$7^{\text {th }}$ November 2016

Companies selected for the study are characterized as similar to the industry they represent. To ascertain the sector specific homogeneity the correlation coefficients between the company returns and the sector returns were calculated by means of multiple regression, corporate returns were dependent variable on the sectoral returns.

\section{Discussion and Analysis}

Table 1: depicts the price reaction prior and post the event time period. The actual returns are converted to $\log$ returns to rule out anomaly in the distribution of the data.

Table 1: Log returns

\begin{tabular}{|l|c|c|c|}
\hline Date & Closing Price & Returns & Log Returns \\
\hline $10 / 24 / 2016$ & 8708.95 & 0.00 & 0.00 \\
\hline $10 / 25 / 2016$ & 8691.30 & 0.00 & 0.00 \\
\hline $10 / 26 / 2016$ & 8615.25 & -0.01 & 0.00 \\
\hline $10 / 27 / 2016$ & 8615.25 & 0.00 & 0.00 \\
\hline $10 / 28 / 2016$ & 8638.00 & 0.00 & 0.00 \\
\hline $11 / 1 / 2016$ & 8626.25 & 0.00 & 0.00 \\
\hline $11 / 2 / 2016$ & 8514.00 & -0.01 & -0.01 \\
\hline $11 / 3 / 2016$ & 8484.95 & 0.00 & 0.00 \\
\hline $11 / 4 / 2016$ & 8433.75 & -0.01 & 0.00 \\
\hline $11 / 7 / 2016$ & 8497.05 & 0.01 & 0.00 \\
\hline
\end{tabular}

Table 2: indicates the association between the Nifty $50(\log )$ and the daily stock returns $(\log )$ of the representative companies of Tata Group. Exogenous variables were assumed to be constant during the event period. The slope - beta value for Tata Motors, Tata Power and Tata Steel depicts co movements with the benchmark index, higher volatility is observed for Tata Steel and Tata Power however inverse relationship can be inferred for TCS stocks. Nifty returns were less impulsive during the event period.

Table: $2 \alpha$ and $\beta$ Values for the 4 Stocks during the estimation period

\begin{tabular}{|l|c|c|c|c|}
\hline variable/Stock & TCS & Tata Power & Tata Steel & Tata Motors \\
\hline Intercept $(\boldsymbol{\alpha})$ & 0.000 & 0.001 & 0.002 & 0.000 \\
\hline X-variable $(\boldsymbol{\beta})$ & -0.072 & 1.211 & 1.756 & 1.813 \\
\hline
\end{tabular}

\subsection{Market Price Reactions on Happening of Event}

Daily abnormal returns were calculated for the select companies on the date of event and postdate event to examine the significance of the event on the shareholders returns as compared to the benchmark returns. Cumulative abnormal returns for TCS scrip was (-0.03882), Tata Steel (-0.01716), Tata power (-0.01341), Tata Motors $(-0.01602)$ as reflected in table $3 \& 4$. Studies evidence for good events, positive cumulative abnormal returns indicate post event drift which represents under reaction of the investors and for bad news negative cumulative abnormal returns represent overreaction of the investors which coincides with the rationale of investment theory. 
Table: 3 Daily Abnormal Returns and Expected Price during the Event Period

\begin{tabular}{|c|c|c|c|c|c|c|c|c|c|c|}
\hline $\begin{array}{l}\text { Year } \\
2016\end{array}$ & \multicolumn{5}{|c|}{ TCS } & \multicolumn{5}{|c|}{ Tata Steel Ltd. } \\
\hline Date & $\begin{array}{l}\text { Closing } \\
\text { Price }\end{array}$ & $\begin{array}{l}\text { Log } \\
\text { Returns }\end{array}$ & DAR & $\begin{array}{l}\text { Antilog } \\
\text { DAR }\end{array}$ & $\begin{array}{l}\text { Exp } \\
\text { price }\end{array}$ & $\begin{array}{l}\text { Closing } \\
\text { Price }\end{array}$ & $\begin{array}{l}\text { Log } \\
\text { Returns }\end{array}$ & DAR & $\begin{array}{l}\text { Antilog } \\
\text { DAR }\end{array}$ & $\begin{array}{l}\text { Exp } \\
\text { price }\end{array}$ \\
\hline $10: 24$ & 2427.70 & 0.00 & 0.00 & 1.00 & 2427.01 & 426.05 & 0.00 & 0.00 & 1.00 & 427.97 \\
\hline $10 / 25$ & 2398.45 & -0.01 & 0.00 & 1.00 & 2410.30 & 415.25 & -0.01 & -0.01 & 0.99 & 420.07 \\
\hline $10 / 26$ & 2396.25 & 0.00 & 0.00 & 1.00 & 2396.90 & 398.60 & -0.02 & -0.01 & 0.99 & 403.82 \\
\hline $10 / 27$ & 2418.10 & 0.00 & 0.00 & 1.00 & 2407.62 & 397.15 & 0.00 & 0.00 & 1.00 & 398.55 \\
\hline $10 / 28$ & 2398.70 & 0.00 & 0.00 & 1.00 & 2405.95 & 405.45 & 0.01 & 0.01 & 1.01 & 403.41 \\
\hline $11 / 7$ & 2350.00 & -0.01 & -0.01 & 0.99 & 2370.18 & 417.70 & 0.01 & 0.01 & 1.01 & 412.70 \\
\hline $11 / 2$ & 2304.05 & -0.01 & -0.01 & 0.99 & 2323.90 & 413.35 & 0.00 & 0.00 & 1.00 & 411.90 \\
\hline $11 / 3$ & 2319.45 & 0.00 & 0.00 & 1.00 & 2312.07 & 403.30 & -0.01 & -0.01 & 0.99 & 407.36 \\
\hline $11 / 4$ & 2330.55 & 0.00 & 0.00 & 1.00 & 2325.23 & 403.10 & 0.00 & 0.00 & 1.00 & 402.11 \\
\hline $11 / 5$ & 2277.05 & -0.01 & -0.02 & 0.98 & 2331.40 & 412.60 & 0.01 & 0.00 & 1.00 & 411.58 \\
\hline \multicolumn{4}{|c|}{. } & -0.04 & \multicolumn{5}{|c|}{ Cumulative Returns } & -0.02 \\
\hline
\end{tabular}

\section{Source: Calculated}

Table 4: Daily Abnormal Returns and Expected Price during the Event Period

\begin{tabular}{|c|c|c|c|c|c|c|c|c|c|c|}
\hline \multirow[b]{2}{*}{ Date } & \multicolumn{5}{|c|}{ Tata Power Ltd } & \multicolumn{5}{|c|}{ Tata Motors Ltd } \\
\hline & $\begin{array}{l}\text { Closing } \\
\text { Price }\end{array}$ & $\begin{array}{l}\text { Log } \\
\text { Returns }\end{array}$ & DAR & $\begin{array}{l}\text { Antilog } \\
\text { DAR }\end{array}$ & $\begin{array}{l}\text { Exp } \\
\text { price }\end{array}$ & $\begin{array}{l}\text { Closing } \\
\text { Price }\end{array}$ & $\begin{array}{l}\text { Log } \\
\text { Returns }\end{array}$ & DAR & $\begin{array}{l}\text { Antilog } \\
\text { DAR }\end{array}$ & Exp price \\
\hline $10 / 24 / 2016$ & 83.65 & 0.00 & 0.00 & 1.00 & 83.91 & 559.80 & 0.01 & 0.01 & 1.01 & 554.03 \\
\hline $10 / 25 / 2016$ & 82.40 & -0.01 & -0.01 & 0.99 & 83.32 & 553.80 & 0.00 & 0.00 & 1.00 & 555.64 \\
\hline $10 / 26 / 2016$ & 80.85 & -0.02 & -0.01 & 0.99 & 82.00 & 530.05 & -0.02 & -0.01 & 0.99 & 536.64 \\
\hline $10 / 27 / 2016$ & 79.55 & 0.00 & 0.00 & 1.00 & 79.76 & 522.00 & -0.01 & -0.01 & 0.99 & 525.61 \\
\hline $10: 28 / 2016$ & 78.30 & 0.01 & 0.01 & 1.01 & 77.79 & 537.00 & 0.01 & 0.01 & 1.01 & 531.67 \\
\hline 11/1/2016 & 78.15 & 0.01 & 0.01 & 1.01 & 77.17 & 530.60 & -0.01 & 0.00 & 1.00 & 532.93 \\
\hline 11/2/2016 & 77.05 & 0.00 & 0.00 & 1.00 & 76.95 & 513.30 & -0.01 & 0.00 & 1.00 & 515.52 \\
\hline 11/3/2016 & 76.70 & -0.01 & -0.01 & 0.99 & 77.46 & 510.20 & 0.00 & 0.00 & 1.00 & 510.29 \\
\hline $11 / 4 / 2016$ & 74.60 & 0.00 & 0.00 & 1.00 & 74.46 & 512.30 & 0.00 & 0.01 & 1.01 & 509.08 \\
\hline $11 / 7 / 2016$ & 75.35 & 0.01 & 0.01 & 1.01 & 74.96 & 506.35 & -0.01 & -0.01 & 0.99 & 512.06 \\
\hline \multicolumn{4}{|c|}{ Cumulative Retums } & -0.01 & \multicolumn{5}{|c|}{ Cumulative Retums } & -0.02 \\
\hline
\end{tabular}

\section{Source: Calculated}

The decline in the security prices of TCS was least as against the peers. Statistical significance test was applied after analyzing the abnormal returns to gauge whether the abnormal returns on account of event had an impact on the share prices independent of the benchmark. To test the level of significance and the impact, $t$ test was applied, with the formulation of Null hypothesis that there existed no difference between the actual and the estimated closing prices.

Table 5: Output for t test

\begin{tabular}{|l|c|c|c|}
\hline Company & $\begin{array}{l}\text { Mean of Actual } \\
\text { closing price }\end{array}$ & $\begin{array}{l}\text { Mean of Estimated } \\
\text { closing price }\end{array}$ & t value \\
\hline TCS & 2362.03 & 2371.05 & $\begin{array}{c}(- \\
0.417)\end{array}$ \\
\hline $\begin{array}{l}\text { Tata Steel } \\
\text { Ltd }\end{array}$ & 409.255 & 409.95 & $\begin{array}{c}(- \\
0.171)\end{array}$ \\
\hline $\begin{array}{l}\text { Tata Power } \\
\text { Ltd. }\end{array}$ & 78.66 & 78.77 & $\begin{array}{c}(- \\
0.084)\end{array}$ \\
\hline $\begin{array}{l}\text { Tata Motors } \\
\text { Ltd }\end{array}$ & 527.54 & 528.34 & $\begin{array}{c}(- \\
0.101)\end{array}$ \\
\hline
\end{tabular}

The researchers found that for all companies the calculated $t$ value was less than $\alpha=0.01$ hence the researchers could reject the null hypothesis proving that there was a significant impact of the event on the stock prices. Earlier studies have suggested that the origin of successor is a critical variable for determining the firm's performance after executive change. Same holds true in case of Tata Group of companies although during the exit of chairman no successor had been identified and the predecessor took over the reins of the Tata Group temporarily, moderate variations in stock prices of the top four companies was witnessed. Investor's belief in Tata's core values, ethical practices and management can be cited as one of the reasons restraining a steep fall in the prices post the announcement.

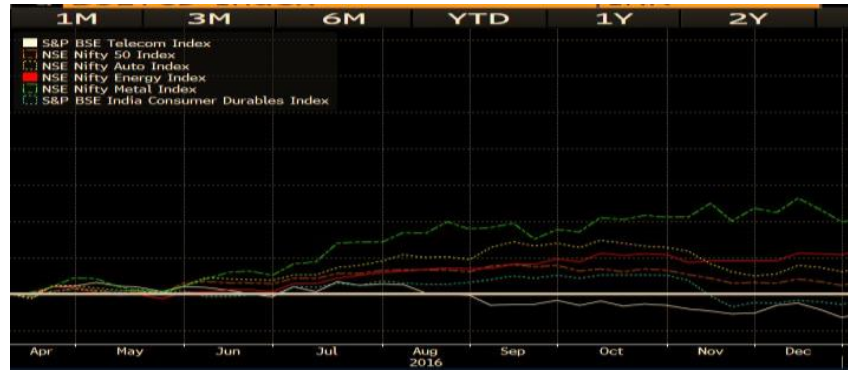

Figure 1: Sectoral Comparative Returns

Source: Bloomberg

NSE Nifty auto index witness higher volatility during the event period cascading the implied effect on the Tata Motors stock returns. Overall other sectoral return index viewed steady rise during the April to July 2017 time frame. Study by Chan(2000) indicate that some investors are slow to react to information, drift occurs in subsequent months that did not have headlines which implies that timing difference occurs to assess the full impact of a single news item on a stock due to frictions. Similar observations coexist for the sectoral returns representing the select stocks; more volatility was seen between the month of November and December than in the event duration. Nifty 50 index returns also showed declining trend from mid-October to November, 2017. It is evident that overall the index showed a down turn, however the news about the ouster of the chairman of the Tata group has not directly impacted the markets. The returns may be driven by buying or selling pressure in response to positive or negative news, capital constraints may impact potential returns.

\section{Conclusion}

Stock markets responds to event information as it anticipates a change in the value of the firm. Unanticipated events outcomes are dependent on the market sentiments and reactions. The study's findings are in conformity with the existing literature on change in board composition. The exit of the chairman lead to negative abnormal returns of the four stocks considered for the study. The researchers have used short time period as they anticipated that long horizon event methods generally have limitations and the immediate impact of the event is quantifiable more effectively in the short run. This paper can be extended to investigate the firm characteristics under different leaderships. Further it can also be applied to relate leadership to the firm value. Studies can be undertaken to evaluate the existence of similar characteristics in different family lead business enterprises.

\section{References}

[1] Armitage, Seth "Event Study Methods and Evidence on their Performance.” Journal of Economic Surveys, Volume: 8(4) (1995), pp: 25-52.

[2] Berkovitch E., and R. Israel, "The design of internal control and capital structure", Review of Financial Studies” Volume: 9, (1996), pp: 209-240.

[3] Binder, John "The Event Study Methodology since 1969." Review of Quantitative Finance and Accounting, Volume: 11(September, 1998), pp: 111-37.

[4] Bowman, Robert "Understanding and Conducting Event Studies." Journal of Business Finance and Accounting, Volume: 10(4), (1983), pp: 561-84.

[5] Carvalho, Carlos, Nicholas Klagge, and Emanuel Moench."The Persistent Effects of a False News Shock," New York Federal Reserve Bank, Staff Report 374 (2011).

[6] Chance, Don, and Stephen Ferris "The Effect of Aviation Disasters on the Air Transport Industry: A Financial Market Perspective.” Journal of Transport Economics and Policy, 21(May,1987): pp:151-65.

[7] Chan, Louis K.C., Narasimhan Jegadeesh, and Josef Lakonishok, “Momentum strategies", Journal of Finance 51, (1996), pp: 16811714. 
[8] Chan, K., Chockalingam, M., \& Lai, K. W "Overnight information and intraday trading behavior: evidence from NYSE cross-listed stocks and their local market information", Journal of Multinational Financial Management, 10(3-4), (2000),pp: 495-509.

[9] Dewatripont, M., and J. Tirole" A theory of debt and equity: Diversity of securities and Manager-shareholder congruence", Quarterly Journal of Economics, (1994), pp:1027-1054.

[10] Furtado, E.P.H., and V. Karan "Causes, consequences, and shareholder wealth effects of management turnover: A review of the empirical evidence", Financial Management 19, (1990), pp: 60-75.

[11] Grinstein, Y., 2000. "The design of leveraged buyout transactions: Theory and tests. Unpublished manuscript"

[12] Haynes, Rachel E., and Scott Schaeffer "How much are differences in managerial abilities worth? Journal of Accounting and Economics 27, (1999), pp: 125-148.

[13] Jensen, Michael, and Richard Ruback. "The Market for Corporate Control: The Scientific Evidence," Journal of Financial Economics 11 (April 1983) pp. 5-50.

[14] Johnson, W.Bruce, Robert Magee, Nandu Nagarajan, and Herry Newman "An Analysis of the Stock Price Reaction to Sudden Executive Death: Implications for the Management Labor Market." Journal of Accounting and Economics, 7(1-3), (1985), pp: 151-74.

[15] Johnston, Margaret "A Review of the Application of Event Studies in Marketing." Academy of Marketing Science Review, 11(4), (2007), pp: 1-31.

[16] Koch, James V., and Robert N. Fenili. "Using event studies to assess the impact of unexpected events." Business Economics 48.1 (2013), pp:58-66.

[17] Koch, James, Robert Fenili, and Richard Cebula "Do Investors Care If Steve Jobs Is Healthy? Atlantic Economic Journal, 39(1), (2011), pp: 39-50.

[18] MacKinlay, A.Craig "Event Studies in Economics and Finance." Journal of Economic Literature, 35(March, 1997), pp: 13-39.

[19] Malmendier, Ulrike M. and Geoffrey Tate "CEO Overconfidence and Corporate Investment," Journal of Finance, Vol. 60 (6), (2005), pp. 2661-2700

[20] McWilliams, Abigail, and Donald Siegel "Event Studies in Management Research: Theoretical and Empirical Issues." Academy of Management Journal, 40(June, 1997): 626-57.

[21] Rosenberg, Joshua V., Matthew J. Clayton, and Jay C. Hartzell 2003. "The Impact of CEO Turnover on Equity Volatility," The Journal of Business, Sep;78(5),(2005),pp.1779-808

[22] Schweitzer, Robert "How do stock returns react to special events." Business Review 8, (1989), pp: 17-29.

[23] Swary, Itzhak "Stock Market Reaction to Regulatory Action in the Continental Illinois Crisis," Journal of Business 59, (1986), pp. 451-73.

[24] Trifts, Jack, and Kevin Scanlon. "Interstate Bank Mergers: The Early Evidence," Journal of Financial Research 10 (winter, 1987), pp. 305-11.

[25] Warner, J.B., Watts, R.L. and Wruck, K.H "Stock prices and top management changes", Journal of financial Economics, 20, (1988), pp.461-492.

[26] Worrell, Dan, Wallace Davidson, P.R. Chandy, and Sharon Garrison "Management Turnover through Deaths of Key Executives: Effects on Investor Wealth." Academy of Management Journal, 29(4), (1986), pp: 674-694. 